\title{
Encephalitis Infection, CTCAE
}

National Cancer Institute

\section{Source}

National Cancer Institute. Encephalitis Infection, CT CAE. NCI Thesaurus. Code C143438.

A disorder characterized by an infectious process involving the brain tissue. 